\title{
Malaysian Primary School ESL Teachers' Questions during Assessment for Learning
}

\author{
Sedigheh Abbasnasab Sardareh ${ }^{1} \&$ Mohd Rashid Mohd Saad ${ }^{1}$ \\ ${ }^{1}$ Department of Language and Literacy Education, Faculty of Education, University of Malaya, Malaysia \\ Correspondence: Sedigheh Abbasnasab Sardareh, Faculty of Education, Department of Language and Literacy \\ Education, University of Malaya, 50603 Kuala Lumpur, Malaysia. E-mail: abbasnasab@gmail.com
}

Received: April 25, 2013 Accepted: May 13, 2013 Online Published: July 4, 2013

doi:10.5539/elt.v6n8p1 URL: http://dx.doi.org/10.5539/elt.v6n8p1

\begin{abstract}
Classroom questioning is a crucial learning and instructional strategy. It has also been regarded as an important aspect of Assessment for Learning (AfL) by researchers. Classroom questioning helps students gain a better appreciation of what they are learning as well as how they are learning. It also helps teachers understand students' learning progress. This qualitative case study is a part of a larger study on classroom questioning during AfL and it has to be reminded that only a part of the study is presented here which involves two ESL teachers (one teaching Year One and the other teaching Year Two class) and the types of questions they used during AfL. The current study was conducted in a selected primary school in Kuala Lumpur, Malaysia. To collect data, ten periods of each teacher's classroom were observed and then interview was conducted with each teacher. Observations and interviews were tape-recorded and transcribed for further analysis. The results of this study showed that the participating teachers were aware of the importance of questioning technique during AfL, however, they asked lower cognitive questions that did not trigger thoughtful reflection. The data also revealed that the teachers in this study formulated questions that at the first sight may seem to be open questions but they expected the students to provide a short-specific answer. Although questions were designed to suit the content of the lesson, it was observed that most of the questions asked by the teachers focused on content, structure and students' background knowledge and elicited specific, predetermined answers. In short, Most of the questions asked by the teachers in their mixed ability classes were below the students' Zone of Proximal Development (ZPD) and did not help the students promote their thinking skills.
\end{abstract}

Keywords: classroom questioning, assessment for learning, lower cognitive questions, qualitative case study

\section{Introduction}

Assessment for Learning (AfL) requires teachers and learners to use assessment to improve instruction and learning. It is about assessing learners' progress, providing them with feedback and deciding on the next step in the teaching and learning process. AfL is not about certifying learning but it rather concentrates on improving learning. Using AfL strategies in the classroom can help teachers fulfill other components of learning such as thinking skills and personal abilities, lifelong learning and mutual understanding (Bennett, 2011; Black \& Wiliam 1998ab).

Classroom questioning is regarded as one of the important AfL strategies (Black \& Wiliam, 2012). Researches acknowledge the importance of classroom questioning as an efficient learning and instructional strategy (Almeida, Pedrosa de Jesus, \& Watts, 2008; Chin \& Osborne, 2008; Graesser \& Olde, 2003) and as an important aspect of AfL (Black, Harrison, Lee, Marshall, \& Wiliam, 2003; Black \& Wiliam, 2012). Classroom questioning helps students gain a better appreciation of what they are learning as well as how they are learning. It also helps teachers understand students' learning progress.

According to Cotton (1983) questions asked by teachers can be lower cognitive questions that include closed, knowledge, factual and recall questions which require students to give short responses based on what they have learned previously and higher cognitive questions that are also referred to as referential, interpretive, evaluative and open-ended questions and require students to create their own answers and help students promote higher order thinking skills.

According to Brown \& Edmondson (1985), the main purpose of classroom questioning is to elicit evidence of 
students' knowledge and understanding, to adapt instruction, to identify students' strengths and weaknesses, to direct their understanding and to maintain classroom control. However, research has shown that questions that teachers ask in their classrooms are usually procedural and factual questions that do not help students increase autonomy. Moreover, other functions of questioning such as motivating students to think, developing their reflections and interest, encouraging students to ask questions and also the importance of questioning as a social construct are usually neglected (e.g., Brown \& Edmondson, 1985; Cooper, 2010; Faizah, 2011; Noorizah, Idris, \& Rosniah, 2012).

The new primary school curriculum in Malaysia puts a great emphasis on AfL. Therefore, this study aimed to investigate Malaysian primary school ESL teachers' questions during AfL to see how they ask questions of their students in accordance with the new assessment system. It should be mentioned that, this qualitative case study is a part of a larger study on classroom questioning during AfL and only a part of the study is presented here which involves two teachers and types of questions they used during AfL in a selected primary school in Kuala Lumpur, Malaysia.

\section{The Current Study}

This qualitative case study was conducted in a selected primary school in Kuala Lumpur, Malaysia. The selected school is one of the top schools in Kuala Lumpur and focuses on AfL in its school plan. The focus of this study is on Year One and Year Two classrooms because AfL is currently being implemented in primary One and Two classes. Two ESL Teachers (one teaching Year One and the other teaching Year Two class) in the selected school took part in this study. The participating teachers hold Bachelor's degree in TESL and their teaching experience range from 9 to 12 years. It should be mentioned that in order to protect teachers' identities, pseudonyms were used. To collect data, ten periods of each teacher's classroom were observed and then interview was conducted with each teacher. Observations and interviews were tape-recorded and transcribed for further analysis.

\section{Results}

The participating teachers frequently used questioning technique in their classrooms but the questions they asked in their mixed ability classes were mostly lower cognitive level questions. Devi, the Year One teacher, asked questions as she entered the class. She usually asked questions like the day and the date, before teaching a topic. Then while teaching she asked questions relevant to the topic. "The basic question that I always ask is "what day is today?' or 'what date is today?' Then I start teaching the new topic" (Devi, Interview). However, most of the questions that Devi asked were lower cognitive level questions. The question types used by this teacher are explained below:

Devi explained to the students that she is going to teach the new lesson. But she did not mention anything about the lesson and the new topic. She started to draw the picture of a human's hand on the white board. The students were sitting at their desks quietly looking at the white board. The teacher finished drawing and started to write the name of each finger on the picture. Then she looked at the students and opened the lesson:

\section{Extract 1}

T: Class, do you know that every finger has name?

Each of this has name ok like this one. What do we call this one? In Bahasa Melayu what do we call this one?

Ss: Ibu jari

T: Ibu jari

What do we call it in English?

What do we call this one? What do we call? Ibu jari, this one here

Thum..? thum? Who wants to answer?

Irfan, thum what? Thumb? Thumpa who else?

$\mathrm{S}_{5}$ : Tampal

T: Tampal? No

This is what we call thumbkin

Ss: Thumbkin

$\mathrm{T}$ : Thumbkin 
Ss: Thumbkin

T: O.K where is thumbkin? Show me your thumbkin. No show me your thumbkin everyone. Alif show me your thumbkin. What is thumbkin, Class? [Apatu thumbkin?]

Ss: Jari

$\mathrm{S}_{2}$ : Jari tangan

T: Jari tangan?

Ss: Ibu jari

$\mathrm{T}$ : So thumbkin or ibu jari.

In the above extract, the teacher used an opening question to start the dialogue with the students. She addressed the question 'Class, do you know that every finger has name?' to all the students but it seems that she was not expecting them to answer the question because after posing the question, she didn't wait for the students to give an answer. Maybe by posing this question, the teacher was only was seeking for the students' non-verbal reaction in order to start the lesson. However, this opening question was a closed question which only required 'yes' or 'no' answer on the part of the learners and didn't provoke thinking.

In the next turn, the teacher pointed to one of the fingers in the picture and asked the students to name it. As can be seen in the extract, the teacher was asking the students to give the name of that particular finger but without waiting for the students to answer the question, she rephrased the question and asked the students to give the name of the finger in Malay. This question was also an example of closed questions that Devi usually used in her classroom. Then she asked the students to give the answer to the same question in English. One of the students gave the wrong answer and after that the teacher herself answered the question without waiting for other students to provide an answer or giving some clues to the students to help them answer the question. When Devi provided the students with the correct answer, all of the students repeated the answer and then the teacher asked them to show their thumbs in order to help them memorize the word.

The above extract is a good example of how Devi was asking closed, display question type in her classroom. This type of question needs a very short, specific response on the part of learners. However, it does not provoke thoughtful reflection and it only requires the learner to provide the right answer. Based on Bloom's classification of question types the questions asked by Devi in the above extract are lower cognitive level questions that only determine the students' level of knowledge. The students only need to remember the name of particular things such as the name of each finger to answer the questions. This question type has one specific answer and do not help students improve higher order thinking skills that is the aim of the new syllabus.

Devi continued the lesson by calling a student to come to the white board and asking question to gauge his understanding on the topic.

\section{Extract 2}

T: Alif come here. Come here, Alif

$\mathrm{S}_{15}$ : Alif

T: In this picture do you think which one is thumbkin? [Daripada gambar ni yang mana satu thumbkin?]

$\mathrm{S}_{15}$ : Thumbkin ini. [This is thumbkin.]

T: O.K

In the above extract the teacher was asking recall questions in order to make sure students have learned the name of each finger. This is also example of closed questions that only requires students display knowledge and recall what they have learned.

Depending on the topic as well as the objectives mentioned in the syllabus specification, Devi often asked WHquestions. "I usually ask WH- questions in my classroom but I think all types of questions related to the topic, even the simple ones are effective. Because it makes students think and recall knowledge to answer my questions" (Devi, Interview). She found out that WH- questions are effective in students' learning and make students think and use their prior knowledge to answer the questions. The following extracts are examples of WH- questions used by this teacher.

\section{Extract 3}

OC-The teacher is drawing a picture of an elephant on the board. 
T: so this is an elephant and this is ... What is this?

$\mathrm{S}_{3}$ : trunk

T: trunk

The topic of this lesson was animals. Devi was asking questions of the students to see if they have learned the name and body parts of animals. In this extract, the teacher was asking WH- questions because she recognized that this type of question is more effective in promoting students' learning. This question required the students to give the name of elephant's body parts. However, it was also a closed, display question and only tested students' knowledge of facts.

\section{Extract 4}

OC-She continued the lesson by asking questions about a turtle:

$\mathrm{T}$ : Look at Look at the turtle.

What you can see from the turtle? [ Apa yang nampak daripada turtle tu?]

OC-Students didn't reply

Amni when you look at the turtle what you can see? [Apa yang nampak?]

$\mathrm{S}_{1}$ : Shell

T: Shell. Other than shell?

$\mathrm{S}_{1}$ : Face

T: Face? Face O.K.

In the above extract, Devi asked WH- question. Yet, at first students couldn't answer the question because this question was an ambiguous question and students were not sure what to answer. If the teacher posed this question to ask the students to name different parts of the body of turtle, students were required to recall different body parts of this animal and answer the question. In this extract, it seems that the teacher was looking for a specific answer because when $S_{1}$ responded to the question the teacher did not give feedback and asked the student to name a part of turtle's body other than shell. When the student mentioned another part of turtle's body, the teacher approved the answer by saying 'O.K' and it shows that the teacher was asking the student to display knowledge and the answer was limited to one acceptable answer.

In the following extract, the teacher asked questions that required the students to give the name of an animal in Bahasa Melayu, however, in the first turn, the teacher was asking a clued question and the answer was included in the question. The following questions are also examples of typical closed questions that aimed to assess students' knowledge.

\section{Extract 5}

T: Crocodile you know crocodile buaya.

Zaree crocodile apa itu in Bahasa Malaysia? [Zaree what is the meaning of crocodile in Malay language?]

$\mathrm{S}_{9}$ : Buaya

T: Buaya. O.K elephant?

Ss: Gajah

T: Dolphin?

Ss: Dolphin

$\mathrm{S}_{6}$ : Lumba-lumba $\uparrow$

T: Lumba-lumba.

While teaching story to her students, Devi asked questions about the story to make students think and predict the events in the story. Nevertheless, the results of classroom observation showed that she was not asking open questions even when teaching stories. Devi pointed out that:

When I read a story I ask them 'what happens next?' I want them to think and predict what happens in the story. For example when I taught them the story of 'the tiny thimble' I asked them 'what will happen when the mother touches the cloth?' so the students look at the picture think about it and answer the question (Devi, Interview).

When teaching the story 'The Tiny Thimble', Devi asked the question she mentioned in the interview. The 
following extract shows how she asked the question:

\section{Extract 6}

T: O.K then when the mother sews... What is sew? Menjahit. Suddenly the cloth changed. What happened to the cloth? What happened? Mishra what happened to the cloth? What happened to the cloth? Who knows?

$\mathrm{S}_{11}$ : Jadi emas [changed to gold]

T: Who can answer me? O.K if you can answer me I give you twenty cents

$\mathrm{S}_{2}$ : What?

S4: Cikgu [Teacher]

T: I give you twenty cents. Who can answer me? O.K Akif what happened to the cloth?

$\mathrm{S}_{16}$ : Cloth?

T: Omar

$\mathrm{S}_{11}$ : Jadi emas [changed to gold]

At the first instance, the question 'What happened to the cloth?' might appear to be an open question requiring the students to predict an event in the story. But as the dialogue progressed, the researcher found out that the question had one specific answer. Meaning that, the teacher was looking for a particular answer. In other words, the answer was embedded in the text and the students had to recall what they have read in the story to answer the question. So, this question did not gauge students' higher order thinking skills. Moreover, when the teacher posed the question, one of the students gave the correct answer in Bahasa Melayu but the teacher didn't pay attention and repeated the question. So students thought this is not the correct answer or maybe they got confused and did not try to answer the question. Finally the same student repeated the answer again. Overall, in an AfL classroom, questioning is considered as a social construct and teachers should ask questions that enhance interaction among the learners and the teacher, yet, the question types asked by the participating teachers does not encourage real life communication.

Then after teaching the story, Devi asked questions about the story. She was asking recall questions to ensure students' understanding. Based on Bloom's classification, these questions only assessed the students' knowledge and required them to recall information to answer the questions.

\section{Extract 7}

T: She is selling the? What is this?

Ss: Bag

T: Selling bags

Ss: Bag

T: Where? [Dekat mana?]

At the market. What is market in Bahasa Malaysia? Pasar. Good.

So she is selling bags.

In order to make the students understand the meaning of the vocabularies in the story, the teacher asked questions:

\section{Extract 8}

T: What is cloth bag? What is bag? You know what is bag, right?

Tau kan beg tu apa? [You know what is bag, don't you?]

Ss: Tau [Yes]

The above extract shows that the teacher asked yes/no question to see if the students understand the meaning of the word 'bag'. This is a closed question because it requires a specific answer and the students can give the answer by only saying yes or no.

Irwan, the Year Two teacher, usually asked How, what, where questions. The types of question he asked of his students were based on the topic he was teaching. "Based on the topic that I am teaching I ask different types of questions. So it depends on the topic. Yet, generally I think WH- questions are effective because this question type 
makes students think" (Irwan, Interview). He used WH- questions more often because he found out that this questions type is more effective and also easier to understand. "Questions must be kept simple and direct, and clear to the students. For example, it is better to ask where do you live? rather than do you live in KL or Selangor?" (Irwan, Interview). Therefore, according to Irwan, questions should not only be simple but also clear and understandable. In the following extracts, Irwan was teaching the topic of recycling. Let's see how he employed WH- questions to teach this topic.

\section{Extract 9}

T: Page 125 it is about recycling

O.K now from that page

What is the title?

T: New-

Ss: New from old

T: New from old

What does that mean?

New you make something new from old products.

The teacher started the lesson by asking students to tell him the lesson title. Irwan employed this opening question to start the dialogue with his students. He asked WH- question but this question is a recall question and students only need to remember the title to answer the question. The next question was also WH- question and the teacher was asking the students to give the meaning of the title. By asking this question, the teacher aimed to check the students' comprehension. He wanted to see if the students were able to understand the meaning of the lesson title and if they could give the meaning of the title in their own words. However, the teacher didn't wait for the students to answer this comprehension question and he answered it himself immediately after posing the question. Irwan continued the lesson by asking the following question:

\section{Extract 10}

From what?

$\mathrm{S}_{4}$ : Tissue

T: oh from tissue

$\mathrm{S}_{2}$ : Plastic

T: Plastics

Very good

Some Ss: Newspaper

T: Newspaper

Plastic bag

Some Ss: Book

\section{T: Book}

Ss: Magazines

T: Yes

Magazines

In the above extract, the teacher was asking the students to give examples of things that can be reused. The students provided different possible answers to this question. This question didn't not require one specific answer; however, the students could answer the question by only giving one-word short responses.

\section{Extract 11}

Then the teacher continued with the following dialogue:

What is that?

Some Ss: Tin

Some Ss: Plastic bottle 
T: Plastic bottle

Very good

O.K all these things you can reuse

To ask the above question in the above extract, the teacher drew a picture on the white board and asked the students to guess the name of the object. The question asked by the teacher was a closed, display question because there was only one possible answer to the question. Moreover, this question checked the students' knowledge of facts and it only required the learner to name the object. Irwan continued the lesson by asking the following questions:

\section{Extract 12}

After you finish reading the newspaper or the magazine, what can you do?

$\mathrm{S}_{9}$ : We can do scrapbook

T: You can do a-?

$\mathrm{S}_{9}$ : Scrapbook

T: Scrapbooks

Very good

What else?

$\mathrm{S}_{11}$ : Bag

T: Bag?

Can you make bag using paper?

Ss: No

T: Bag. I don't think so

But you can make-

What?

You put letter inside

$\mathrm{S}_{3}$ : Cards

$\mathrm{S}_{7}$ : Paper

$\mathrm{T}$ : What is it?

It is a

$\mathrm{S}_{7}: \mathrm{XXXX}$

$\mathrm{T}: \mathrm{No}$

You put when you want to send the letter you put inside the letter.

$\mathrm{S}_{11}$ : Paper bag

T: Yes you can make paper bag

And then beside that you can make what?

$\mathrm{S}_{6}$ : Origami

$\mathrm{T}$ : *Envelop*

Because the answer is envelope.

Using the papers, the newspaper or the magazine you can make envelope.

At first, it might seem that the teacher was asking an open/referential question because the question required students to name things they could make reusing newspaper. However, as the exchange progressed it became apparent that the teacher had a specific answer in mind. The students provided two possible answers but the teacher was expecting one specific answer which was 'envelope'. He didn't reject the possible answers given by the students but tried to guide them to provide the correct answer and finally he provided the answer himself. This type of question is called pseudo question. At first it might seem that the teacher accepts variety of different responses but he/she has decides on the correct answer and expects students to give the desired answer. The following extract shows another example of this question type used by Irwan: 


\section{Extract 13}

T: Tin or plastic tin or maybe aluminum tin. What can you use that? You put your coin inside. You can make what?

$\mathrm{S}_{12}$ : Tabung

T: What is tabung in English?

$\mathrm{S}_{2}$ : Pretty bag

T: Oh you can make pretty bag O.K. What is tabung in English?

$\mathrm{S}_{11}$ : Coin box

There might be different possible answers to the question in the above extract but the teacher expected one specific answer which was coin box. Therefore, we couldn't consider this question as an open question. Irwan also asked yes/no questions. The following extract from the same lesson shows how he employed this type of question. As mentioned before, this question type is a closed question with specific answer (yes/no).

\section{Extract 14}

Do you know how to make paper planes?

Ss: Yes

T: Yes but don't do it here. Do at home. All right

So use can do a lot of things using the papers and plastic also like Plastic flower. Have you seen plastic flowers before?

Ss: Yes

T: Yes very nice. Very beautiful and very expensive too.

\section{Discussion and Conclusion}

The results of this study showed that although the participating teachers were aware of the importance of questioning technique during AfL, they asked lower cognitive questions that do not trigger thoughtful reflection. These findings are relatively aligned with the findings of Faizah (2011) and Noorizah et al. (2012) which revealed that teachers in Malaysian primary schools ask closed/display questions which do not promote thinking skills. The results of the current study on questioning during AfL expanded the findings of previous studies and revealed that the teachers in this study formulated questions that at the first sight may seem to be open questions but they expected the students to provide a short-specific answer. An example of this question type is the question asked by Irwan 'After you finished reading the newspaper, the magazine what can you do?' this question might seem to be an open question that make students think and give ideas, however, the teacher expects the students to give a specific answer which is 'envelope'. According to Black and Wiliam (1998a) questions that require students to give one specific answer, do not help students come up with their own answers and enhance their learning that is the aim of AfL.

In an AfL Classroom, questioning is considered as a social phenomenon that might vary according to the intention behind the question. Question should elicit communicative response. So, teachers need to ask questions that encourage students' meaning construction rather than eliciting preconceived knowledge and understanding. Although questions were designed to suit the content of the lesson, it was observed that most of the questions asked by the teachers focused on students' background knowledge, content and structure and elicited specific, predetermined answers.

As Berk (2009, p. 265) mentioned "students perform at their best when they are working within their ZPD". However, most of the questions asked by the teachers in their mixed ability classrooms were below the students' ZPD and did not help the students promote their thinking skills. This finding is inconsistent with Berk (2009) findings that according to Vygotsky's sociocultural theory, teachers need to formulate questions that make students go beyond giving simple, short-specific answers and also make them think and reflect on an issue rather than merely discovering the correct answer. Therefore, it is expected that teachers pose more open questions, ask probing questions and help students to develop their own responses with less assistance. Developing a question progression before teaching the lesson can help teacher to implement classroom questioning effectively in mixed ability classrooms.

\section{Acknowledgements}

The authors thank all participants in this study for their kind cooperation. 


\section{References}

Almeida, P. A., Pedrosa de Jesus, H., \& Watts, M. (2008). Developing a mini-project: Students' questions and learning styles. The Psychology of Education Review, 32, 6-17.

Bennett, R. E. (2011). Formative assessment: A critical review. Assessment in Education: Principles, policy \& Practice, 18(1), 5-25. http://dx.doi.org/10.1080/0969594X.2010.513678

Berk, L. (2009). Child development (8th ed.). Boston, MA: Pearson Education.

Black, P., Harrison, C., Lee, C., Marshall, B., \& Wiliam, D. (2003). Assessment for learning: Putting it into practice. Buckingham, UK: Open University Press.

Black, P., \& Wiliam, D. (1998a). Assessment and classroom learning. Assessment in Education: Principles, Policy and Practice, 5(1), 7-74.

Black, P., \& Wiliam, D. (1998b). Inside the black box: Raising standards through classroom assessment. Phi Delta Kappan, 80(2), 139-148.

Black, P., \& Wiliam, D. (2012). Developing a theory of formative assessment. In J. Gardner (Ed.), Assessment and Learning (2nd ed., pp. 206-229). London, UK: Sage. http://dx.doi.org/10.4135/9781446250808.n13

Brown, G. A., \& Edmondson, R. (1985). Asking questions. In E. C. Wragg (Ed.), Classroom teaching skills (pp. 97-120). London, UK: Croom Helm.

Chin, C., \& Osborne, J. (2008). Students' questions: A potential resource for teaching and learning science. Studies in Science Education, 44, 1-39. http://dx.doi.org/10.1080/03057260701828101

Cooper, R. (2010). Those who can teach (12th ed.). Boston, MA: Wadsworth Cengage Learning.

Cotton, K. (1983, February). Classroom Questioning. Paper presented at the annual meeting of the Association of Teacher Educators, Orlando, Florida.

Faizah, M. (2011). School-based assessment in Malaysian schools: The concerns of English teachers. Journal of US-China Education Review, 8(10), 1-15.

Graesser, A., \& Olde, B. (2003). How does one know whether a person understands a device? The quality of the questions the person asks when the device breaks down. Journal of Educational Psychology, 95, 524-536. http://dx.doi.org/10.1037/0022-0663.95.3.524

Noorizah, M. N., Idris, A., \& Rosniah, M. (2012). Teachers' questioning approaches in the Malaysian ESL classroom. The International Journal of Learning, 18(7), 313-326.

\section{Copyrights}

Copyright for this article is retained by the author(s), with first publication rights granted to the journal.

This is an open-access article distributed under the terms and conditions of the Creative Commons Attribution license (http://creativecommons.org/licenses/by/3.0/). 